\title{
Changes in climate, ocean and ice-sheet conditions in the Ross embayment, Antarctica, at 6 ka
}

\author{
Eric J. Steig, ${ }^{1}$ Charles P. Hart, James W. C. White, Wendy L. Cunningham, ${ }^{1}$ \\ Mathew D. Davis, ${ }^{2}$ Eric S. Saltzman ${ }^{2}$ \\ ${ }^{1}$ Institute of Arctic and Alpine Research, University of Colorado, Boulder, CO 80309, U.S.A. \\ ${ }^{2}$ Rosenstiel School of Marine and Atmospheric Science, University of Miami, Miami, FL 33149, U.S.A.
}

\begin{abstract}
Evidence from the Ross embayment, Antarctica, suggests an abrupt cooling and a concomitant increase in sea-ice cover at about $6000 \mathrm{BP}(6 \mathrm{ka})$. Stable-isotope $(\delta \mathrm{D})$ concentrations in the Taylor Dome ice core, at the western edge of the Ross embayment, decline rapidly after $6 \mathrm{ka}$, and continue to decline through the late Holocene. Methanesulfonic acid concentrations at Taylor Dome show opposite trends to $\delta \mathrm{D}$. Sediment cores from the western Ross Sea show a percentage minimum for the sea-ice diatom Fragilariopsis curta between 9 and $6 \mathrm{ka}$, when Taylor Dome $\delta \mathrm{D}$ values are highest, followed by an increase through the late Holocene. Radiocarbon dates from raised beach deposits indicate that the retreat of ice shelves in the Ross embayment ceased at about $6 \mathrm{ka}$, coincident with the environmental changes inferred from the sediment and ice-core records. The similarity in timing suggests an important role for climate in controlling the evolution of ice-shelf margins following the end of the last glaciation.
\end{abstract}

\section{INTRODUCTION}

The late-Wisconsin and Holocene glacial history of the Ross Sea embayment, Antarctica (Fig. 1), has been the subject of extensive research since the early part of this century (Scott, 1905; Hollin, 1962; Mercer, 1968; Denton and others, 1991). Glacial geologic records show that the Ross Ice Shelf once extended some $2000 \mathrm{~km}$ further north than it does today, and that a grounded Ross Sea ice sheet extended into the Dry Valleys; retreat of the ice-sheet grounding line began by about $14000 \mathrm{BP}$ (14 ka) (Stuiver and others, 1981; Denton and others, 1989; Licht and others, 1996). It seems clear from the timing of grounding-line retreat - coincident with the melting of Northern Hemisphere ice sheets - that rising sea level played a dominant role in the initiation of deglaciation in the Ross embayment (Thomas and Bentley, 1978; Denton and others, 1986). Less well understood is the relationship between regional climate and continued evolution of the ice-shelf margin after the end of the last glaciation. In particular, changes in ocean temperatures, which control ice-shelf basal melting rates, could have played an important role in determining the rate and timing of ice-shelf margin retreat (Thomas and others, 1984; MacAyeal and others, 1986; Rott and others, 1996).

In this paper, we present new data from the Taylor Dome ice core, at the western margin of the Ross embayment. Stable-isotope and methanesulfonic acid concentrations in the Taylor Dome core indicate that warm conditions prevailed in the early Holocene, followed by rapid cooling at about $6 \mathrm{ka}$ and continued climatic deterioration through the late Holocene. Inferred mid- to late-Holocene cooling is corroborated by preliminary results from Ross Sea sediment cores, which show an increase in percentages of seaice diatoms after $6 \mathrm{ka}$. A review of the literature of radiocarbon-dated macrofossils from raised beach deposits provides independent control on marine environmental conditions in coastal Antarctica, and suggests that changes in climate in the Ross embayment had an important influence on the evolution of ice-shelf margins.

\section{EVIDENCE FROM THE TAYLOR DOME ICE CORE}

Taylor Dome is located just inland of the Transantarctic Mountains across McMurdo Sound from Ross Island, Antarctica. Taylor Dome is a local ice-accumulation area that

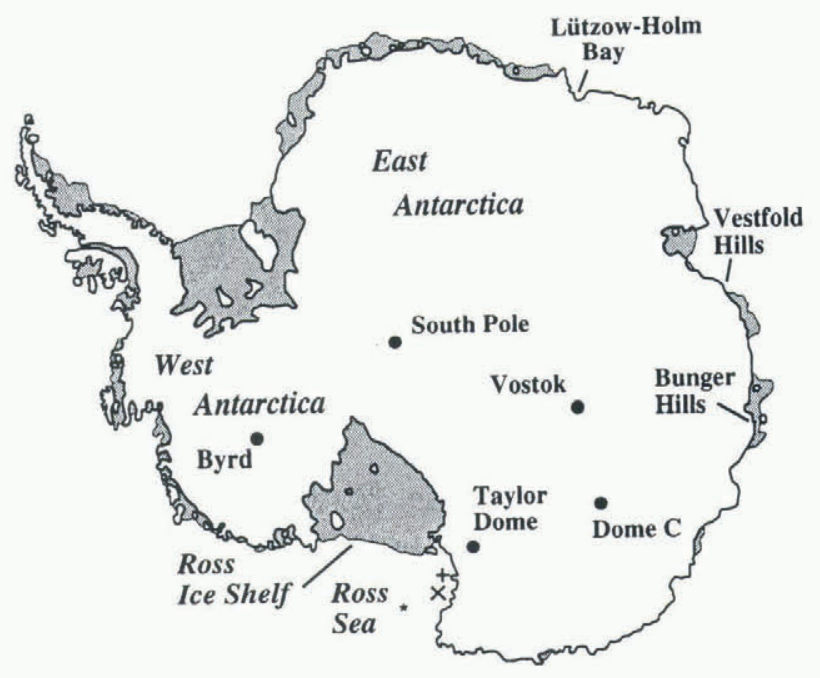

Fig. 1. Map of Antarctica, showing locations mentioned in the text. Shaded areas are ice shelves. Ross Sea sediment cores are shown by plus sign (core NBP9501-KC31), cross ( NBP9501KC37) and star (NBP9501-KC39). Terra Nova Bay is on the coast between cores 31 and 37. McMurdo Sound is the small embayment to the right (west) of the Ross Ice Shelf. 
supplies ice to Taylor Glacier to the southeast and to the Skelton Névé to the southwest. A $554 \mathrm{~m}$ ice core retrieved at Taylor Dome in early 1994 yields a climate record through marine isotope stage 5e (Grootes and others, 1994). Glaciological reconstructions, constrained by the glacial-geologic record at the margins of Taylor Glacier, show that the height of Taylor Dome has changed by at most $160 \mathrm{~m}$ in the last $1 \mathrm{Ma}$, and by far less in the last $100 \mathrm{ka}$ (Marchant and others, 1994). Thus, the isotope profile at Taylor Dome should not be significantly affected by elevation change. Taylor Dome differs in this respect from many other long ice cores in Antarctica, including Vostok (central East Antarctica) and Byrd Station (central West Antarctica), which may have experienced significant elevation change since the Last Glacial Maximum (Jenssen, 1983; Grootes and Stuiver, 1986).

We measured deuterium isotope concentrations $(\delta \mathrm{D}$, the $\mathrm{D} / \mathrm{H}$ ratio normalized to a value of $\delta \mathrm{D}_{\mathrm{V} \text {-SMOW }}=0 \%$ ) and methanesulfonic acid concentrations $\left(\mathrm{CH}_{3} \mathrm{SO}_{3} \mathrm{H}\right.$ or MSA) at $\sim 0.5 \mathrm{~m}$ resolution through the Wisconsin-Holocene transition at about $375 \mathrm{~m}$ in the Taylor Dome ice core. Analyses for $\delta \mathrm{D}$ were performed at the University of Colorado, according to the methods discussed by Vaughn (1994). MSA concentrations were measured at the University of Miami, according to methods described by Whung and others (1994). The time-scale for the Taylor Dome core is based on a finite-element flow model, constrained by radar profiling and surface velocity data, and accumulation rates from ${ }^{10} \mathrm{Be}$ concentrations, as discussed by Steig (1996), Morse (1997) and Steig and others (1998). We estimate that this time-scale is accurate to about $10 \%$ during the Holocene, as indicated by an independent comparison with the GISP2 ice core on the basis of high-resolution trace-gas $\left(\mathrm{CH}_{4}\right.$ and $\delta^{18} \mathrm{O}$ of $\left.\mathrm{O}_{2}\right)$ measurements.

Figure 2 shows $\delta \mathrm{D}$ and MSA at Taylor Dome during the Holocene, with Vostok $\delta$ D (Jouzel and others, 1993) for comparison. Figure 2 also shows sea-ice diatom percentages from western Ross Sea sediment cores, discussed in the following section. Clearly, isotopic changes at Taylor Dome during the Holocene are much larger in magnitude than at Vostok, and are anticorrelated with MSA. The "early Holocene warm period", as inferred from relatively high $\delta \mathrm{D}$ values, ends by about $8 \mathrm{ka}$ at Vostok, as at other sites in central East Antarctica (Ciais and others, 1992). At Taylor Dome, high $\delta \mathrm{D}$ values last until about $6 \mathrm{ka}$. Between about 9 and $6 \mathrm{ka}, \delta \mathrm{D}$ values are higher than at any other time since the previous interglacial period. At $6 \mathrm{ka}, \delta \mathrm{D}$ drops by a full $10 \%$, and then declines more gradually towards the present by another $10 \%$.

The $\delta \mathrm{D}$ concentration in polar precipitation is widely accepted as a proxy for temperature (Dansgaard and others, 1973). The most straightforward interpretation of the $\delta \mathrm{D}$ profile at Taylor Dome core is that it reflects rapid cooling at $6 \mathrm{ka}$ followed by continued climatic deterioration through the late Holocene. This cooling was evidently restricted to coastal regions, since it does not appear in the Vostok record (Ciais and others, 1992). Although recent work in central Greenland shows that the slope of the isotope-temperature relationship cannot be assumed to be constant at all temporal scales, it may be reasonable to assume that a linear relationship applies for the Holocene (Cuffey and others, 1995). For central East Antarctica, Jouzel and others (1996) use a $\partial \delta \mathrm{D} / \partial \mathrm{T}$ gradient of $9 \%{ }^{\circ} \mathrm{C}^{-1}$. Applying the same relationship to the Taylor

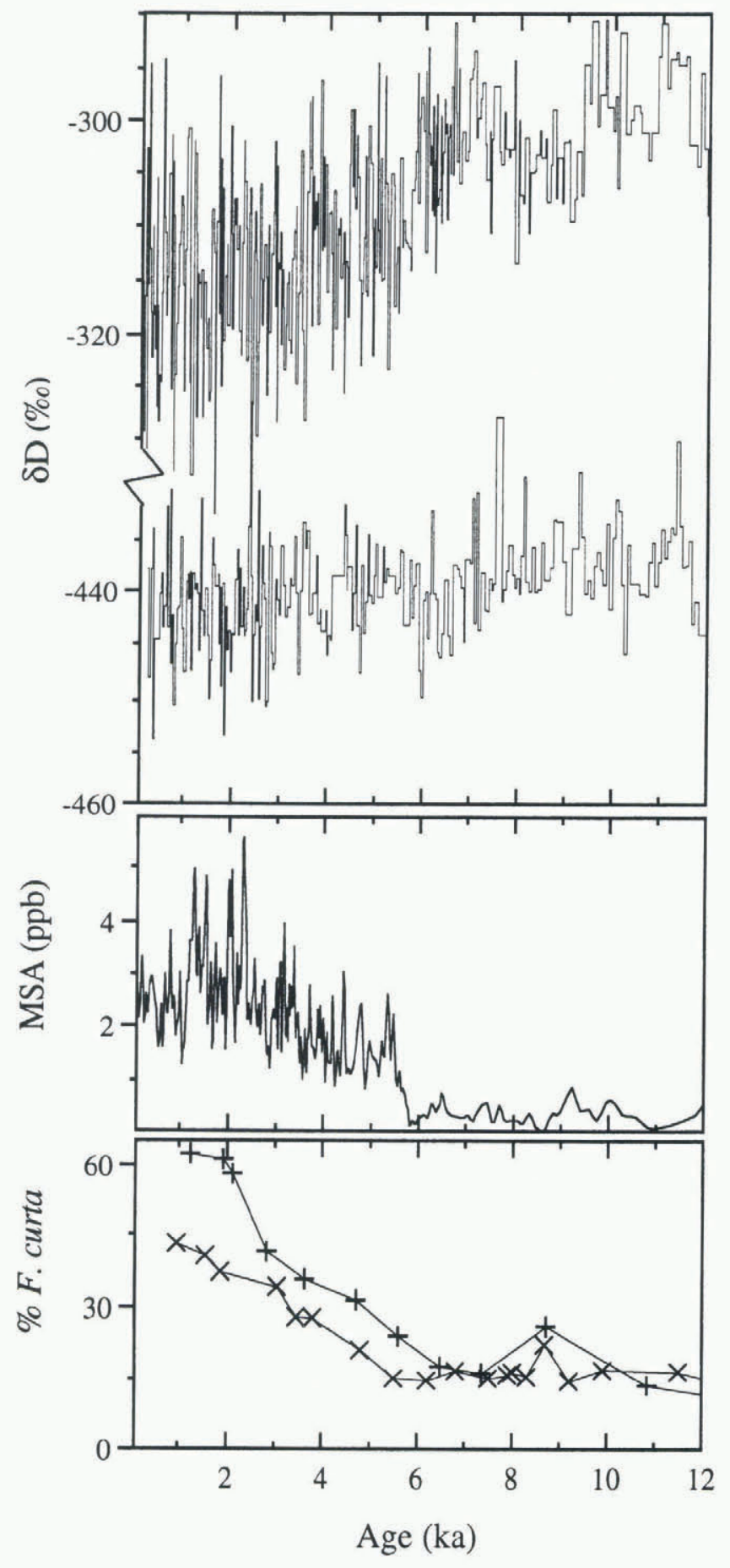

Fig. 2. Top panel: stable-isotope concentrations at Taylor Dome (upper) and Vostok (lower). Middle panel: MSA concentrations at Taylor Dome. Bottom panel: abundance of Fragilariopsis curta in sediment cores from the western Ross Sea: plus signs, core NBP9501-KC31; crosses, core NBP9501-KC37.

Dome core, this indicates a cooling of about $2^{\circ} \mathrm{C}$ between $6 \mathrm{ka}$ and the present, in good agreement with results from borehole paleothermometry (Waddington and Clow, 1997).

The importance of seasonal changes in moisture sources and in the timing of precipitation in determining mean annual isotope values has been emphasized recently in the literature (Charles and others, 1994; Steig and others, 1994; Fawcett and others, 1997). Changes in $\delta \mathrm{D}$ may not be strictly related to temperature. At Taylor Dome, only $150 \mathrm{~km}$ from seasonally open water, $\delta \mathrm{D}$ may be particularly sensitive to the seasonal influence of sea-ice cover. According to model 
estimates, a $1 \%$ decrease in $\delta \mathrm{D}$ for coastal Antarctica would require a northward increase in winter sea-ice extent of only $0.2^{\circ}$ of latitude (Bromwich and Weaver, 1983). The effect of sea ice on $\delta \mathrm{D}$ largely reflects the increased distance to the moisture source during the period of maximum precipitation (mostly in winter). Increased sea ice, either locally in the Ross embayment or Antarctica-wide, may additionally delay summer warming (Hanna, 1996), resulting in a decrease in the relative proportion of summer (high $\delta \mathrm{D}$ ) snowfall in the annual average.

The MSA profile in the Taylor Dome ice core (Fig. 2) supports the inference that the $\delta \mathrm{D}$ decrease since $6 \mathrm{ka}$ in part reflects an increase in sea-ice cover. MSA is an oxidation product of dimethylsulfide (DMS), which is produced by certain marine algae, especially in polar waters (see Saltzman, 1995, for a review). A positive correlation between sea-ice cover and MSA deposition at the ice-sheet surface is postulated to result from enhanced productivity of DMS-producing algae during high-sea-ice years (see Legrand, 1995, for a review). In particular, Phaeocystis is an abundant component of pack-ice algal assemblages (Garrison and others, 1987) and is a major producer of DMS (Gibson and others, 1989). Although the environmental factors determining the distribution and abundance of Phaeocystis are not fully understood (Leventer and Dunbar, 1996), Phaeocystis blooms are probably favored by stabilization of the water column resulting from sea-ice melt-out (Smith and Nelson, 1985; DiTullio and Smith, 1995).

A positive correlation between sea-ice cover and MSA concentration has been observed for at least two Antarctic ice cores (Peel and Mulvaney, 1992; Welch and others, 1993). Welch and others (1993) report that the correlation between sea ice and MSA is not statistically significant at Taylor Dome; however, the period of comparison is less than 20 years and the changes in MSA concentration are small. For the Holocene, MSA and $\delta \mathrm{D}$ at Taylor Dome are strongly anticorrelated: MSA values are lowest between 9 and $6 \mathrm{ka}$, where $\delta \mathrm{D}$ values are highest, while MSA increases rapidly at $6 \mathrm{ka}$ and continues to rise throughout the Holocene, with a total change of more than a factor of five. Taken together, the MSA and $\delta \mathrm{D}$ data in the Taylor Dome core both suggest cooler temperatures and increased sea ice since $6 \mathrm{ka}$ in the Ross embayment.

\section{MICROFOSSIL EVIDENCE FROM ROSS SEA SEDI- MENT CORES}

Independent evidence for colder conditions and/or increased sea-ice cover since 6 ka comes from the microfossil record in the Ross Sea. Burckle (1972) and Kellogg and Truesdale (1979) used diatom assemblages from sediment cores to infer both cooling and increased sea-ice extent around Antarctica during the late Holocene. We report here results from cores obtained from cruise 9501 of the $\mathrm{R} / \mathrm{V}$ Nathaniel B. Palmer in the Ross Sea which support this earlier research. Because this work is still in progress, we report data only for kasten cores NBP9501-KC31, NBP9501-KC37 and NBP9501-KC39, obtained respectively from basins at water depths of 879,924 and $557 \mathrm{~m}$. Also, we report data only for the dominant diatom species in these cores, Fragilariopsis curta.

Chronologies were obtained by interpolation of ten radiocarbon dates (one every $\sim 1000$ years) on bulk organic matter in each core, measured by accelerator mass spectrometry at the University of Arizona (Cunningham, 1997). Due to the potential of reworking of organic carbon in Ross Sea shelf sediments (Hart and others, 1996), all ages must be considered maximum ages. There are, however, no age reversals during the Holocene portions of the cores, and calculated sedimentation rates are essentially constant, giving us confidence in the chronologies. A correction factor of 1200 years is applied to account for Antarctic marine ${ }^{14} \mathrm{C}$ reservoir effects (Gordon and Harkness, 1992). We converted the reservoir-corrected dates to calendar age using the calibration of Stuiver and Reimer (1993); for corrected ages greater than 9000 radiocarbon years BP we use the U-Th calibration of Bard and others (1993).

The bottom panel in Figure 2 shows Fragilariopsis curta abundance (percentage by number of diatoms counted) vs age for cores 31 and 37 . Between 9 and $6 \mathrm{ka}, F$. curta percentages are low, generally below $20 \%$. After $6 \mathrm{ka}$, they increase steadily to $40-65 \%$. Surveys of modern Ross Sea diatom assemblages show that $F$. curta is common in both fast ice and pack ice and may be considered an indicator of seasonal sea-ice cover (e.g. Truesdale and Kellogg, 1979; Leventer and Dunbar, 1996). Thus, the $F$. curta profiles in both of these western Ross Sea cores suggest increased seaice cover since about $6 \mathrm{ka}$, in excellent agreement with our inference from the Taylor Dome ice-core data. Increased sea-ice cover may have been limited to coastal areas: $F$. curta percentages in core NBP9501-KC39, from the central Ross Sea, do not change appreciably throughout the entire Holocene (Cunningham, 1997).

\section{MACROFOSSIL EVIDENCE FROM RAISED BEACH DEPOSITS}

Assemblages of molluscs on isostatically uplifted beach deposits are known from a number of locations in coastal East Antarctica, including the Ross embayment (see Berkman, 1992, for a summary). These assemblages are found as both in situ placements and wave-reworked shell accumulations. A compilation of radiocarbon dates from these assemblages, and from ice-shelf uplifted macrofossils in southern McMurdo Sound (Kellogg and others, 1990), suggests that the environmental changes recorded in the Taylor Dome ice core and Ross Sea sediment cores may coincide with the last phase of ice-shelf retreat in the Ross embayment.

The chronology of deglaciation in the Ross embayment is based largely on radiocarbon dates from terrestrial and marine glacial deposits (e.g. Stuiver and others, 1981). Using such data, Denton and others (1989) and Licht and others (1996) showed that grounded ice had retreated from McMurdo Sound by $7 \mathrm{ka}$; this date gives a minimum estimate for ice-sheet grounding-line retreat. A chronology restricted to fossil samples collected from ice shelves and raised beach deposits can be used to date the establishment of full marine conditions in a particular locale. This reflects more directly the existence of ice shelves or sea ice, as opposed to an ice-sheet grounding line (Denton and others, 1991). Because withdrawal of ice shelves is not a prerequisite for colonization of an area by benthic invertebrates (Hain and Melles, 1994), such a chronology should yield a maximum age for ice-shelf retreat.

Figure 3 shows histograms of radiocarbon dates compiled for (1) coastal East Antarctica excluding the Ross em- 

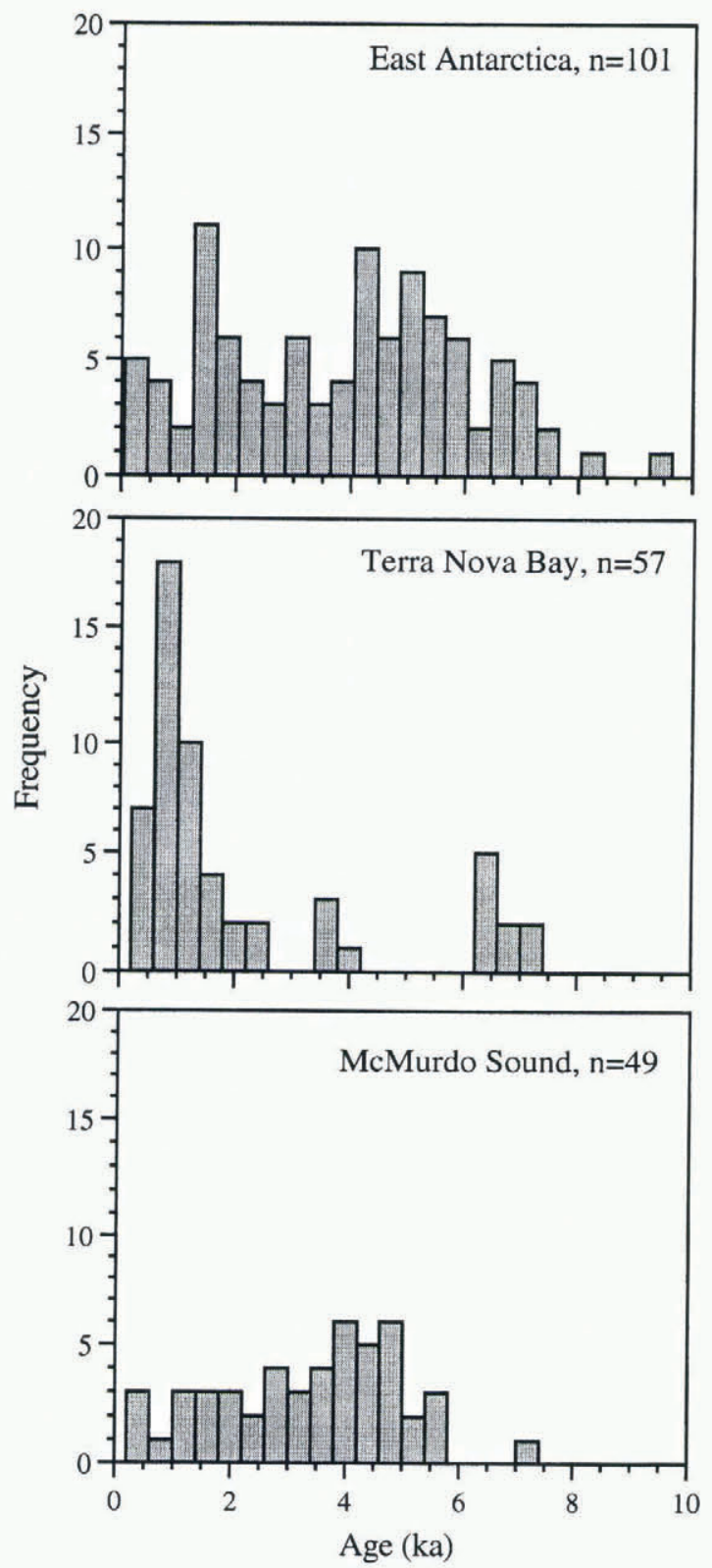

Fig. 3. Histograms of published radiocarbon dates (converted to calendar age) from raised beach deposits from East Antarctica excluding the Ross embayment, and from Terra Nova Bay, and from raised beaches and ice-shelf sediments in southern McMurdo Sound. References are given in the text.

bayment (Pickard, 1985; Adamson and Colhoun, 1992; Hayashi and Yoshida, 1994; Igarashi and others, 1995a, b); (2) Terra Nova Bay, northwestern Ross embayment (Baroni and others, 1991); and (3) southwestern Ross embayment/ McMurdo Sound (Stuiver and others, 1981; Kellogg and others, 1990). Sampling locations are shown on the map in Figure 1. Radiocarbon studies on modern Antarctic invertebrates collected prior to 1945 (and therefore uncontaminated by bomb- ${ }^{14} \mathrm{C}$ ) suggest that species-specific reservoir corrections might be appropriate (Berkman and Forman, 1996). For this review we use a reservoir correction of 1400 years for dates from the scallop Adamussium colbecki and a correction of 1200 years for all other analyses on carbonate shells. The corrected data have been calibrated according to Stuiver and Reimer (1993), as described above for the Ross Sea sediment cores.

The upper histogram in Figure 3 shows that the estab- lishment of marine conditions dates to about $7.5 \mathrm{ka}$ or earlier in most coastal settings in East Antarctica. This almost certainly reflects the rapid response of both ice-sheet grounding lines and ice-shelf margins to eustatic sea level, which was still rising at this time (Bard and others, 1990). Ice-shelf retreat may have continued past $7.5 \mathrm{ka}$, but there are insufficient data to address this possibility. For the Ross embayment, the data reveal a more complex deglaciation history. Stuiver and others (1981) and Denton and others (1989) note the absence of any raised-beach deposits in southernmost McMurdo Sound. They suggest that ice-sheet grounding-line retreat in the Ross embayment was followed by an "ice-shelf phase" which continued until some time after 7 ka. At Terra Nova Bay (Fig. 3), retreat of the Ross Ice Shelf exposed beaches by about $7.5 \mathrm{ka}$, but there may have been a readvance of local ice shelves after $6 \mathrm{ka}$, reflected in the low number of dates between 2.5 and $6 \mathrm{ka}$ (Baroni and Orombelli, 1994). Thus, the ice margin at Terra Nova Bay was either stable or undergoing continued retreat until $6 \mathrm{ka}$. For the southwestern Ross embayment (southern McMurdo Sound), there is one calibrated date of $7.1 \mathrm{ka}$ (Fig. 3). This is from uplifted debris from beneath the McMurdo Ice Shelf (an extension of the Ross Ice Shelf); all other dates, mostly from raised beaches, are $6 \mathrm{ka}$ or younger. Taken together, the radiocarbon data from Terra Nova Bay and southern McMurdo Sound suggest that ice-shelf retreat continued in the Ross embayment until about $6 \mathrm{ka}$.

\section{DISGUSSION}

The geochemical and isotopic data at Taylor Dome and the microfossil evidence from Ross Sea sediment cores show that $6 \mathrm{ka}$ is an important temporal boundary for climate conditions in the Ross embayment. The bulk of the evidence points to an extended length for the "early Holocene climatic optimum", which is generally taken to have ended at about $8 \mathrm{ka}$ (Ciais and others, 1992), and to lower temperatures and increased sea-ice cover through the late Holocene.

Denton and others (1986) have argued that sea level played a dominant role in the initiation of deglaciation in the Ross embayment following the end of the last glaciation. They further suggest that retreat of the Ross Ice Shelf margin led to increased southward advection of warm ocean water, which contributed to regionally increased precipitation rates and higher temperatures, accounting for Holocene advances of alpine glaciers in the Dry Valleys. For the early Holocene, data from the Taylor Dome ice core tend to support this concept: temperatures at Taylor Dome, as inferred from $\delta \mathrm{D}$, are highest at about 9 and $11 \mathrm{ka}$, well after the initiation of ice-sheet retreat. Also, Steig (1997) showed that the increase in accumulation rate between the last glaciation and the present was greater at Taylor Dome than at Vostok and other more inland sites.

Our compilation of radiocarbon dates suggests that $6 \mathrm{ka}$ at least roughly marks a maximum for Holocene ice-shelf retreat in the Ross embayment. This agrees rather well with the evidence given above for warmer ocean and atmospheric conditions until $6 \mathrm{ka}$, suggesting an important role for climate in controlling the timing of ice-shelf retreat. Certainly, the recent collapse of the Larsen Ice Shelf on the Antarctic Peninsula illustrates the importance of ocean surface temperatures in controlling ice-shelf dynamics (Rott and others, 1996). Thus, for the mid-Holocene, warm 
ocean-surface temperatures may have contributed to continued evolution of ice-shelf margins, while the abrupt cooling at about $6 \mathrm{ka}$ stabilized the margin and prevented further retreat. Continued cooler air and sea-surface temperatures through the late Holocene suggest the possibility that the current position of the ice-shelf margin does not represent the Holocene minimum, but could reflect at least a minor readvance since $6 \mathrm{ka}$.

\section{ACKNOWLEDGEMENTS}

This work was supported by grants from the U.S. National Science Foundation (OPP-9526979, 8919524, 9222178). The manuscript benefited greatly from helpful reviews by A. Leventer and an anonymous reviewer.

\section{REFERENCES}

Adamson, D. A. and E. A. Colhoun. 1992. Late Quaternary glaciation and deglaciation of the Bunger Hills, Antarctica. Antarct. Sci., 4 (4), 435-446.

Bard, E., B. Hamelin and R. G. Fairbanks. 1990. U-Th ages obtained by mass spectrometry in corals from Barbados: sea level during the past 130,000 years. Nature, 346(6283), 456-458.

Bard, E., M. Arnold, R. G. Fairbanks and B. Hamelin. $1993 .{ }^{230} \mathrm{Th}-{ }^{234} \mathrm{U}$ and ${ }^{14} \mathrm{C}$ ages obtained by mass spectrometry on corals. Radiocarbon, 35(1), 191-199.

Baroni, C. and G. Orombelli. 1994. Holocene glacier variations in the Terra Nova Bay area (Victoria Land, Antarctica). Antarct. Sci., 6(4), 497-505.

Baroni, C., G. Belluomini, M. E. Branca, S. Improta and G. Orombelli. 1991. Radiocarbon dates from Terra Nova Bay (Victoria Land, Antarctica): conventional and calibrated ages. Mem. Soc. Geol. Ital., 46, 81-92.

Berkman, P. A. 1992. Circumpolar distribution of Holocene marine fossils in Antarctic beaches. Quat. Res., 37 (2), 256-260.

Berkman, P. A. and S. L. Forman. 1996. Pre-bomb radiocarbon and the reservoir correction for calcareous marine species in the Southern Ocean. Geophys. Res. Lett., $23(4), 363-366$.

Bromwich, D. H. and C. J. Weaver. 1983. Latitudinal displacement from main moisture source controls $\delta^{18} \mathrm{O}$ of snow in coastal Antarctica. Nature, 301 (5896), 145-147.

Burckle, L. H. 1972. Diatom evidence bearing on the Holocene in the South Atlantic. Quat. Res., 2(3), 323-326.

Charles, C. D., R. Rind, J. Jouzel, R. D. Koester and R. G. Fairbanks. 1994. Glacial-interglacial changes in moisture sources for Greenland: influences on the ice core record of climate. Science, 263 (5146), 508-511.

Ciais, P. and 6 others. 1992. Evidence for an early Holocene climatic optimum in the Antarctic deep-ice-core record. Climate Dyn., 6(3-4), 169-177.

Cuffey, K. M., G. D. Clow, R. B. Alley, M. Stuiver, E. D. Waddington and R.W. Saltus. 1995. Large Arctic temperature change at the WisconsinHolocene glacial transition. Science, 270(5235), 455-458.

Cunningham, W. L. 1997. The use of modern fossil diatom assemblages as climate proxies in the central and western Ross Sea, Antarctica. (M.Sc. thesis, University of Colorado.)

Dansgaard, W., S.J. Johnsen, H. B. Clausen and N. Gundestrup. 1973. Stable isotope glaciology. Medd. Gronl., 197(2).

Denton, G. H., T. J. Hughes and W. Karlén. 1986. Global ice-sheet system interlocked by sea level. Quat. Res., 26(1), 3-26.

Denton, G. H., J. G. Bockheim, S. C. Wilson and M. Stuiver. 1989. Late Wisconsin and Early Holocene glacial history, inner Ross embayment, Antarctica. Quat. Res., 31 (2), 151-182.

Denton, G. H., M. L. Prentice and L. H. Burckle. 1991. Cainozoic history of the Antarctic ice sheet. In Tingey, R. J., ed. The geology of Antarctica. Oxford, Clarendon Press, 365-433.

DíTullio, G. R. and W. O. Smith. 1995. Relationship between dimethylsulfide and phytoplankton pigment concentrations in the Ross Sea, Antarctica. Deep-Sea Res., Ser. I, 42 (6), 873-892.

Fawcett, P.J., A. M. Agústsdóttir, R. B. Alley and C. A. Shuman. 1997. The Younger Dryas termination and North Atlantic deep water formation: insights from climate model simulations and Greenland ice core data. Paleoceanography, 12(1), 23-28.

Garrison, D. L., K. R. Buck and G. A. Fryxell. 1987. Algal assemblages in Antarctic pack ice and in ice-edge plankton. 7. Phycol., 23 (4), 564-572.

Gibson, J. A. E., R. C. Garrick, H. R. Burton and A. R. McTaggart. 1989. Dimethylsulphide and the alga Phaeocystis pouchetii in Antarctic coastal waters. Mar. Biol., 104(2), 339-346.

Gordon, J. E. and D. D. Harkness. 1992. Magnitude and geographic varia- tion of the radiocarbon content in Antarctic marine life: implications for reservoir corrections in radiocarbon dating. Quat. Sci. Rev., 11 (7-8), 697-708.

Grootes, P. M. and M. Stuiver. 1986. Ross Ice Shelf oxygen isotopes and West Antarctic climate history. Quat. Res., 26(1), 49-67.

Grootes, P. M., E. J. Steig and M. Stuiver. 1994. Taylor ice dome study 19931994: an ice core to bedrock. Antarct. 7. U.S., 29(5), 79-81.

Hain, S. and M. Melles. 1994. Evidence for a marine molluscan fauna beneath ice shelves in the Lazarev and Weddell seas, Antarctica, from shells of Adamussium colbecki and Nacella (Patinigera) cf. concinna. Antarct. Sci., 6(1), 29-36.

Hanna, E. 1996. The role of Antarctic sea ice in global climate change. Prog. Phys. Geogr., 20(4), 371-401.

Hart, C. P., C.W. Ward and P. -N. Webb. 1996. Amino acid based geochronology from glacial-marine sediment cores, Ross Sea, Antarctica. Geol. Soc. Am. Abstr. Programs, $28(7), 506$.

Hayashi, M. and Y. Yoshida. 1994. Holocene raised beaches in the LützowHolm Bay region, East Antarctica. Nat. Inst. Polar Res. Mem., Special Issue $50,49-84$

Hollin, J. R. 1962. On the glacial history of Antarctica. J. Glaciol., 4(32), 172-195.

Igarashi, A., N. Harada and K. Moriwaki. 1995a. Marine fossils of 30-40 ka in raised beach deposits, and late Pleistocene glacial history around Lützow-Holm Bay, East Antarctica. Proc. NIPR Symp. Antarc. Geosci. 8, $219-229$.

Igarashi, A., H. Numanami,Y. Tsuchiya, N. Harada, M. Fukuchi andT. Saito. 1995b. Radiocarbon ages of molluscan shell fossils in raised beach deposits along the east coast of Lützow-Holm Bay, Antarctica, determined by accelerator mass-spectrometry. Proc. NIPR Symp. Polar Biol.8, 154-162.

Jenssen, D. 1983. Elevation and climatic change from total gas content and stable isotopic measurements. In Robin, G. de Q., ed. The climatic record in polar ice sheets. Cambridge, Cambridge University Press, 138-144.

Jouzel, J. and 16 others. 1993. Extending the Vostok ice-core record of palaeoclimate to the penultimate glacial period. Nature, 364 (6436), 407-411.

Jouzel, J. and 13 others. 1996. Climatic interpretation of the recently extended Vostok ice core records. Climate Dyn., 12(8), 513-521.

Kellogg, T. B. and R. S. Truesdale. 1979. Late Quaternary paleoecology and paleoclimatology of the Ross Sea: the diatom record. Mar. MicroPalaeontol., 4(2), 137-158.

Kellogg, T. B., D. E. Kellogg and M. Stuiver. 1990. Late Quaternary history of the southwestern Ross Sea: evidence from debris bands on the McMurdo Ice Shelf, Antarctica. In Bentley, C. R., ed. Contributions to Antarctic research I. Washington, DC, American Geophysical Union, 25-56. (Antarctic Research Series 50.)

Legrand, M. 1995. Sulphur-derived species in polar ice: a review. In Delmas, R. J., ed. Ice core studies of global biogeochemical cycles. Berlin, etc., SpringerVerlag, 91-119. (NATO ASI Series I: Global Environmental Change 30.)

Leventer, A. and R. B. Dunbar. 1996. Factors influencing the distribution of diatoms and other algae in the Ross Sea. 7. Geophys. Res., 101 (C8), 18,48918,550 .

Licht, K. J., A. E. Jennings, J. T. Andrews and K. M. Williams. 1996. Chronology of the late Wisconsin ice retreat from the western Ross Sea, Antarctica. Geology, 24(3), 223-226.

MacAyeal, D. R., S. Shabtaie, C. R. Bentley and S. D. King. 1986. Formulation of ice shelf dynamic boundary conditions in terms of a Coulomb rheology. 7. Geophys. Res., 91 (B8), 8177-8191.

Marchant, D. R., G. H. Denton, J. G. Bockheim, S. C. Wilson and A. R. Kerr. 1994. Quaternary changes in level of the upper Taylor Glacier, Antarctica: implications for paleoclimate and East Antarctic ice sheet dynamics. Boreas, 23(1), 29-43.

Mercer, J. H. 1968. Glacial geology of the Reedy Glacier area, Antarctica. Geol. Soc. Am. Bull., 79 (4), 471-486.

Morse, D. L. 1997. Glacier geophysics at Taylor Dome, Antarctica. (Ph.D. thesis, University of Washington.)

Peel, D. A. and R. Mulvaney. 1992. Time-trends in the pattern of oceanatmosphere exchange in an ice core from the Weddell Sea sector of Antarctica. Tellus, 44B (4), 430-442.

Pickard, J. 1985. The Holocene fossil marine macrofauna of the Vestfold Hills, East Antarctica. Boreas, 14(2), 189-202.

Rott, H., P. Skvarca and T. Nagler. 1996. Rapid collapse of northern Larsen Ice Shelf, Antarctica. Science, 271 (5250), 788-792.

Saltzman, E.S. 1995. Ocean/atmosphere cycling of dimethylsulfide. In Delmas, R. J., ed. Ice core studies of global biogeochemical cycles. Berlin, etc., Springer-Verlag, 65-90. (NATO ASI Series I: Global Environmental Change 30.)

Scott, R. F. 1905. The voyage of the 'Discovery?' Vol. 1-2. London, Smith, Elder.

Smith, W. O. and D. Nelson. 1985. Phytoplankton bloom produced by a receding ice edge in the Ross Sea: spatial coherence with the density field. Science, 227(4683), 163-166. 
Steig, E.J. 1996. Beryllium-10 in the Taylor Dome ice core: applications to Antarctic glaciology and paleoclimatology. (Ph.D. thesis, University of Washington.)

Steig, E. J. 1997. How well can we parameterize past accumulation rates in polar ice sheets? Ann. Glaciol., 25, 418-422.

Steig, E. J., P. M. Grootes and M. Stuiver. 1994. Seasonal precipitation timing and ice core records. Science, 266(5192), 1885-1886.

Steig, E. J., D. L. Morse, E. D. Waddington and P.J. Polissar. 1998. Using the sunspot cycle to date ice cores. Geophys. Res. Lett., 25(2), 163-166.

Stuiver, M. and P.J. Reimer. 1993. Extended ${ }^{14} \mathrm{C}$ data base and revised CALIB $3.0{ }^{14} \mathrm{C}$ age calibration program. Radiocarbon, 35(1), 215-230.

Stuiver, M., G. H. Denton, T.J. Hughes and J. L. Fastook. 1981. History of the marine ice sheet in West Antarctica during the last glaciation: a working hypothesis. In Denton, G. H. and T. J. Hughes, eds. The last great ice sheets. New York, etc., John Wiley and Sons, 319-436.

Thomas, R. H. and C. R. Bentley. 1978. A model for Holocene retreat of the West Antarctic ice sheet. Quat. Res., 10(2), 150-170.

Thomas, R. H., D. R. MacAyeal, D. H. Eilers and D. R. Gaylord. 1984. Gla- ciological studies on the Ross Ice Shelf, Antarctica, 1973-1978. In Hayes, D. and C. R. Bentley, eds. The Ross Ice Shelf: glaciology and geophysics. Washington, DC, American Geophysical Union, 21-53. (Antarctic Research Series 42.)

Truesdale, R. S. and T. B. Kellogg. 1979. Ross Sea diatoms: modern assemblage distributions and their relationship to ecologic oceanographic, and sedimentary conditions. Mar. Micro-Palaeontol., 4(1), 19-31.

Vaughn, B. 1994. Stable isotopes as hydrologic tracers in South Cascade Glacier. (M.Sc. thesis, University of Colorado.)

Waddington, E. D. and G. D. Clow. 1997. Warming in south Victoria Land, Antarctica from borehole thermometry. [Abstract.] EOS, 78(46), Fall Meeting Supplement, F41-F42.

Welch, K. A., P. A. Mayewski and S. I. Whitlow. 1993. Methanesulfonic acid in coastal Antarctic snow related to sea ice extent. Geophys. Res. Lett. 20(6), 443-446.

Whung, P. -Y., E. S. Saltzman, M. J. Spencer, P. A. Mayewski and N. Gundestrup. 1994. Two-hundred-year record of biogenic sulfur in a south Greenland ice core (20D). 7. Geophys. Res., 99(Dl), 1147-1156. 